\title{
FEDERALIST PLANS IN CENTRAL AND EASTERN EUROPE AND THE QUESTION OF THE BALTIC STATES IN THE CONTEXT OF POLISH POLITICS DURING WORLD WAR II
}

\author{
Tadeusz Kisielewski
}

ABSTRACT This paper deals with federalist plans of Central and Eastern Europe during World War II. The Polish government in exile and its Czechoslovak counterpart actively participated in the implementation of such plans. A Central- and Eastern European federation was to be an eventual alternative to Stalin's plans of Europe's Sovietization and to Hitler's 'New Europe'.

For some time these federalist plans were supported by Great Britain and the United States. Besides, in British and American circles there were also other models for creating a European regional union.

On 11 November 1940 Poland and Czechoslovakia managed to sign a declaration on the formation of a federation. However, soon disagreements concerning attitudes towards the Soviet Union as well as over Lithuania's place in the federation arose.

The Second World War broke out on 1 September 1939 when Poland was attacked by Germany and by the Soviet Union on 17 September of the same year, and not as it is sometimes maintained in Germany that allegedly the 1939 war against Poland was merely an introduction to World War II, the Weimarischer Krieg. Neither are many Russians right, further escalating the attitude of the former USSR and arguing that World War II started on 22 June 1941 when Germany invaded the USSR. By attacking Poland, Germany and the USSR changed radically the political situation of Europe mainly because the most influential Western European powers, Great Britain and France whose appeasement policy then failed totally, became involved in the war from 3 September 1939. Adolf Hitler and Joseph Stalin were bound by a treaty, the so-called Ribbentrop-Molotov Pact, which made them responsible for the outbreak of the Second World War. Additionally, in 1939 they divided the territory of Central and Eastern Europe into their spheres of influence. 
Another event fraught with serious political consequences both for the West and for the East was the unexpected crushing defeat of France in June 1940. When on 22 June 1941 Germany attacked the Soviet Union, the latter soon became an ally of Great Britain, and after the United States' entry into the war in December of the same year, it also became a partner of this superpower. Thus, these three great powers made up a 'Big Three', conducting an autonomous policy of the anti-German Alliance. Franklin D. Roosevelt and Winston Churchill lost no time in forgetting Stalin's recent union with Hitler. Immediately after Germany's defeat Stalin revived his ideological and political hostility towards the capitalist democratic West and endeavoured to implement his old idea of communism conquering the whole of Europe and the world. He returned to the Soviet Union the countries and territories which were to the east of the sphere of influence, established by the USSR and Germany in September 1939 and subsequently brought under his control the countries bounded by the Bug, the Carpathian mountains, the Elbe and the Adriatic Sea. The United States and Great Britain sanctioned these actions. Taking that situation into account one can maintain that in Central and Eastern Europe the Second World War (and its consequences) were over in a sense only when (1) some Central and European countries which though not part of the USSR but depending on it became independent again, (2) Germany recovered its full political sovereignty after the dismantling of the Berlin Wall, and (3) Lithuania, Latvia, Estonia and Moldova annexed by the USSR in 1940 and 1944 as well as other countries previously captured by the Bolsheviks - Ukraine and Belarus - achieved their independence only when the USSR lost the rivalry with the West and collapsed. This process started in 1989, and in Poland it was preceded by the moral and political Solidarity (Solidarność) revolution in 1980. In this new situation in Central and Eastern Europe in 1989 the struggle for independence was especially pronounced in Lithuania which set an example for other nations incorporated into the USSR. That can hardly be treated as a coincidence if one takes into account the fact that it was in Lithuania that the anti-Soviet resistance and partisan movements were the longest, most intensive and heroic after the Second World War. This is clearly attested in Bronius Makauskas' meticulous research - these post-war events could not but remain in the consciousness of the people despite all kinds of repression and 'communist education'. In the post-war years resistance and partisan movements were launched not only in the Baltic countries but also 
in Ukraine and particularly in its western part and in Poland, and that was the continuation of the war.

The outbreak of the World War II meant the end of the Treaty of Versailles in Europe. In the changed situation the three great European powers - Germany, the USSR and Great Britain - fighting for the domination on the continent created three different conception of the post-war reconstruction of Europe. Meanwhile the United States sought to prevent the division of Europe that could be a cause of a new world war. In the beginning the Americans supported the British conception of the formation of a Union of Central Europe, but later, when Moscow opposed the appearance of such a union, abandoned that idea. Both big English-speaking states welcomed the Soviet sphere of influence from the Elbe to the Adriatic Sea in Europe. Nevertheless Washington supported London's striving to prevent the destabilization of Western Europe and its dependence on the Soviet Union and to preclude its occupation of Greece and at least a part of Iran. The leaders of smaller European countries also had their own conceptions of post-war Europe and in particular of their region. In this context the Polish government in exile played an important role as an unmistakably influential partner of the antiGerman Alliance.

The Soviet Union constantly strove to have a Moscow-controlled Europe consisting of Soviet republics and extending to at least the English Channel. Only a world war could help implement this idea - the victory of the Bolshevik revolution had become a reality only in the aftermath of the First World War. However, at that time it failed to spread out throughout Europe mainly due to the fact that Bolshevik Russia lost the war in August in the battle at Warsaw and at the Nemunas in September and had to retreat eastwards. The Treaty of Riga was signed in March 1921, thus marking the end of the war and becoming an important guarantee of peace in the East as a kind of supplement to the Treaty of Versailles in this region. Throughout the entire inter-war period Moscow endeavoured to destabilize the post-war order in Europe. In Stalin's opinion, having extended its sphere of influence to the Elbe and the Adriatic Sea after World War II, the USSR had realized its aims only partially.

Having lost the war to France, Germany initiated (actually unofficially) the unification and assumption of control of Europe by creating a new structure on the continent. German diplomats sought support for this blueprint from smaller neutral European countries, 
in particular in the Balkans. This German initiative worried the British and especially the Poles: they feared that that initiative might be supported too actively by the then neutral America. Polish concern is reflected in Marian Seyda's letter of 27 October 1940 to Gen. Kazimierz Sosnkowski; both of them were leading members of the London-based Polish government in exile. Seyda inter alia wrote: "Hitler's move to create "a new structure for Europe" the basis of which would be a German-Italian treaty with the Vichy government of France and General Franco can isolate England and create a great danger to Poland. Hitler's aim is to form the image of a moral consolidator of the so far fallen-out Europe and to persuade the United States not to become engaged in the war and let their leaders think that Hitler's conception of the reconstruction of the European continent is still useful to the USA and "is beneficial to American trade". In Seyda's view, it was possible that the United States would recognize Great Britain's right to its territories and interests in exchange for the latter's recognition of Hitler's control of the mainland of Europe. 'Ultimately the world would be divided into two or three blocs: the German bloc controlling Europe, the Englishspeaking bloc comprising America and the British Empire and the bloc of Japan and Asia. Thus the nations of Europe could be enslaved possibly for centuries, and the fate of Poland would be most dreadful, simply tragic'. Therefore Seyda insisted 'on the governments of Poland and Czechoslovakia making ... a joint declaration. They had to state that the two of them would form a postwar union that could be a nucleus of a new Central European political system, accepting other nations on the basis of full equality'. It was necessary to show that 'in contrast to Hitler's tyrannical concept, Britain and its allies had their own positive concept of how a greater part of the continent of Europe should be organized on the principles of freedom and equality'. ${ }^{1}$ This Polish-Czechoslovak declaration was issued soon on 11 November 1940.

At that time Great Britain favoured a more general idea of the reconstruction of post-war European regional federations/confederations; practically, however, it supported the idea of a Central European federation/confederation as a barrier between Germany and the Soviet Union, capable of defending itself from the militarism of the two superpowers. Already in 1939 a group of various British aca-

${ }^{1}$ A. XII. 34/2, Kol. Gen. K. Sosnkowskiego. Letter of 27 October 1940. Sikorski Institute Archive, London (henceforth SIA). 
demics had begun analyzing a possibility of regional federations in Europe. Subsequently some researchers of other nations joined the British. A rather numerous group of British federalists had been proclaiming long before the necessity of a British-French-German federation as the beginning of a common European federation. This group was ready to implement their idea immediately, however, with a Germany without Hitler. There were adherents of a federation consisting only of Great Britain and France, while others were for a federation of the British Empire and the United States. The Polish interior minister Professor Stanisław Kot thus commented the concept of the British federalists to the government: 'The literature of British federalists clearly emphasizes the inclusion of Germany in the federation. This tendency has not been estimated accurately and the probable role of Poland has been ignored'. Thus in the envisioned Europe the principal roles had to be played by Great Britain and Germany, and France could be accepted, too. Germany had 'to penetrate eastwards much further than the pre-war Germany through Poland and Czechoslovakia, no matter whether they would be accepted to the European federation or not'. Not a single British federalist saw a place for the Soviet Union in the European federation, since the federation proper was directed against it. Kot concluded that 'it is hardly believable that the government of Great Britain should be willing to raise overtly the issue of the European federation during the war', as it feared Soviet opposition, because there was no other powerful ally in the entire continent. Kot proposed that 'relations between Poland and Czechoslovakia should be improved' 'to enable the formation of a Polish, Czech and Slovak Union, in due course accepting Lithuania, Romania, Hungary and Yugoslavia. ${ }^{2}$ Since the autumn of 1939 the British government had been supporting the idea of a post-war Central European union, consisting of Poland, Czechoslovakia and Hungary and did not offer any other conceptions of governing this part of the continent.

The Polish government in exile, albeit in general terms, also contemplated the issue of re-organizing post-war continental Europe. In 1939 and at the start of 1940 the then foreign minister August Zaleski, relying on the League of Nations, presented a conception of 'the European Union', which would consist of regional federations. The basis of the inter-state relations would be economic

${ }^{2}$ Kol. St. Kota, sygn. 470. Opracowanie - Federalizm. Archiwum Zakładu Historii Ruchu Ludowego, Warsaw. 
cooperation. Subsequently ideas about a multi-bloc Europe emerged in the Polish government. Five regional blocs were meant: (1) Central Europe (Poland, Czechoslovakia, Lithuania and Romania), (2) the Latin bloc (France, Italy, Spain and Portugal), (3) the German bloc (Germany and Austria), (4) the Northern bloc (Belgium, Netherlands, Luxembourg, Denmark, Norway and Sweden) and (5) the Balkan bloc (Greece, Bulgaria, Yugoslavia and Albania).

This plan was not discussed in more detail. ${ }^{3}$ According to the Polish government and its premier Władisław Sikorski the continent of Europe was to be divided into western and eastern parts. To bring this idea into effect the future regional federations were supposed to cooperate closely and not to compete with one another. Each regional federation could establish partnership relations with the great powers. Of course, these ideas (albeit not formulated) originated in the context of contemporary considerations of a European federation and reflected contemporary needs and political views.

The formation of a Polish-Czechoslovak or Polish-Czech-Slovak union was intended to precede the implementation of the Central European federation/confederation. The need for such an alliance was discussed in Czech and Slovak circles as early as March 1939, shortly after the fall of the Czech and Slovak state, and in the Polish sphere soon after the defeat of Poland in September of the same year. Before the war the former Czechoslovak premier, Milan Hodža, had argued for a closer Polish-Czechoslovak union. As prime minister and leader of the Slovak landowners he put forward this idea in talks with the Polish Populist leader Wincent Witos, living in emigration between 1933 and $1939 .{ }^{4}$ Before the war relations between Poland and Czechoslovakia were not particularly good mainly because a political and military treaty as demanded by Warsaw between Poland and Czechoslovakia was not been signed. That treaty was supposed to be similar to those concluded between Poland and France and between Poland and Romania, so as to deter Germany and curtail the USSR's games to provoke disagreements between Poland and Czechoslovakia. Here we might note that throughout the entire inter-war period the USSR constantly sought to undermine Polish policy by sowing strife between the Poles and the

3 J. Skodlarski, Epilog układu Sikorski-Beneš. Z dziejów polskoczechosłowackich w latach 1939-1949 (Łódź, 1988), p. 42.

${ }^{4}$ Cf. W. Witos, Moja tułaczka 1933-1939, (Warsaw, 1967), p. 174. 
Lithuanians in every possible way. Poland and Czechoslovakia acted as rivals in Central Europe despite exhortation from France, the chief continental guarantor of the Treaty of Versailles, for them to cooperate as closely as possible, and Poland disregarded the proposal to join the Little Entente. Prague was also against that step because it feared that the Little Entente would be directed against Germany and the USSR, and that would provoke their enmity. Meanwhile, without Poland's participation, Czechoslovakia restricted itself to the struggle against territorial revisionism by Hungary, whose territory had been reduced to the benefit of its neighbours.

After their defeat in 1939 the Poles, Czechs and Slovaks wanted to do away with the tradition of bad Polish-Czechoslovak relations as quickly as possible and acknowledged that joint action was of paramount importance for their people to cooperate more closely and broadly in Central Europe. An attempt to form a union comprising Poland, Czechoslovakia and Central Europe was a response to the doubts of 1938-1939 over whether smaller and weaker countries would be able to remain independent and autonomous in a Europe which was then undergoing transformation. It is important that the British were interested most in such a union.

After the Fall of France the Polish and the provisional Czechoslovak governments in exile moved to London. The Polish government and its premier Sikorski became actively involved in the issues concerning the future of Poland and Czechoslovakia and of a Central European Federation in October and November 1939. During their talks with the Polish prime minister and the foreign minister the British presented their plan of creating a Polish-Czechoslovak-Hungarian Federation, the aim of which would be to maintain a balance between Germany and the USSR. The Poles welcomed the British proposal. However, as the contemporary Polish ambassador to Great Britain, Edward Raczyński, noted, 'the attempts to open talks on this subject with the Czechoslovak politicians were unsuccessful at first due to Beneš's opposition and subsequently because Britain and France took up an anti-Soviet stance following the so-called Finnish War. ...Then there was the defeat on the Western front and France eventually ceased to exist'. He also stated: 'To talk about the Oxford Englishmen, the views of Sir Bernard Pares and Professor Hugh Seton-Watson, maintaining friendly relations with ex-President Beneš, on the question of Central and Eastern Europe coincide: they do not support the idea of a federation. Meanwhile Russia's great expansion to the West is regarded by them as a big blow to Germany in 
Europe. ...The fact that Russia has returned to European affairs and that the great Slav state has approached the German eastern borders ensures not only the existence of the "smaller" Slav nations but also a balance in Europe'. 5 According to this conception and taking into account the reality of a German-Soviet conflict, this was a sanction not only recognizing the Soviet-annexed eastern lands which had belonged to Poland before the war but also assigning the whole of Central Europe within the sphere of the Soviet Union. Later Seton-Watson became an adherent of a Central European Federation and was one of the principal advisers of the British government on this issue.

The pre-war partners of the Polish government were the president of Czechoslovakia, Beneš, a Czech, and the premier Hodža, a Slovak. Both of them suffered a political defeat and after the decisions of the Munich Conference found themselves in exile. Soon Beneš outrivalled Hodža politically and became a partner of the Polish government. Before the start of serious negotiations concerning a union between Poland and Czechoslovakia Beneš required that a Czechoslovak government should be established in exile. Paris, however, was opposed to this condition, and the government was established in London after the defeat of France. It is noteworthy that in the beginning Beneš's policy was oriented towards the Soviet Union. He considered that a federation of Poland, Czechoslovakia and Central Europe could be established only with the approval of the Soviet Union. He was certain that sooner or later the Soviet Union would be at war with Germany and that after the defeat of the latter it would become a decisive factor in the East. At the same time Beneš persisted in his opinion that after the war Poland's efforts to recover the boundaries fixed by the Treaty of Riga could not be supported. He insisted on improving relations with Moscow and was in favour of a smaller Poland, which would be unable to dominate in a future Polish-Czechoslovak union. The Polish government was also intent upon maintaining friendly relations with the USSR and was not willing to create a Central European Union, thereby coming into conflict with this great power. Nevertheless, it considered that Poland and Czechoslovakia should be independent politically and intended to re-organize Central Europe and resist the policy of Moscow aimed at subjugating this region. And it also sought to enlist

${ }^{5}$ SIA, A. XII. 49/Cz/1A. Kol. E. Raczyńskiego. Raczyński’s note of 30 Jan. 1940. 
the support of Great Britain and the United States. Beneš and Sikorski had different opinions, because the former favoured a looser confederate union between Poland and Czechoslovakia based on economic interests, while the latter envisaged a close political and military Polish-Czechoslovak federation.

Polish politicians suspected that Beneš was more interested in Czechoslovak-Soviet relations than relations between Poland and Czechoslovakia and the idea of a union between Poland, Czechoslovakia and Central Europe, and, what was worse, that he yielded easily to the influence of Moscow. His Czechoslovak opponents, Milan Hodža and General Lev Prchala explicitly stated that he was an exponent of Soviet policy. No matter how their opinion can be regarded, the fact remains that the negotiations on a union between Poland, Czechoslovakia and Central Europe proceeded slowly despite repeated Polish attempts to intensify them. In the middle of 1942 the discussions ran into serious difficulties and finally on 17 March 1943 Czechoslovak representatives broke off the talks undoubtedly under Soviet pressure. Already at that time Beneš was engaged in negotiating a treaty of friendship, mutual assistance and cooperation between Czechoslovakia and the USSR, which was signed in Moscow on 12 December 1943.

Why did the idea of a union between Poland, Czechoslovakia and Central Europe come to nothing? Firstly, in 1942 Great Britain and, subsequently, the United States stopped supporting this plan. Secondly, the Czechoslovak side was under increasing pressure of Moscow to discontinue the negotiations with the Poles on the formation of the union. The Czechoslovak government in emigration comprised Communists who pursued a Stalinist policy, and that complicated Czechoslovakia's situation. After the collapse of this plan this part of Europe passed under Soviet rule. ${ }^{6}$

On 11 November 1940, the anniversary of Germany's capitulation in the Second World War, the Polish and the provisional Czechoslovak governments issued a joint declaration in which both governments expressed their will after the war to establish 'a closer political and economic union which could serve a basis for a newly reconstructed Central Europe...? 7 The declaration was a kind of response

${ }^{6}$ In greater detail, see T. Kisielewski, Federacja środkowoeuropejska. Pertraktacje polsko-czechostowackie 1939-1943 (Warsaw, 1991). These questions are also discussed in other Polish and Czech publications.

7 This text is published in an appendix to Kisielwski, Federacja środkowoeuropejska. 
to 'the New Order in Europe', inaugurated by Hitler, and it was advantageous to the British Foreign Office. The statement was important in respect to time - it was issued a fortnight before Italy's attack on Greece and coincided with Viacheslav Molotov's visit to Berlin. This declaration was the only significant joint action to form a union between Poland, Czechoslovakia and Central Europe.

Poland envisaged that the future union of Central Europe would also comprise Hungary, Romania and Lithuania. In an unsigned analysis of 5 November 1940, found among Polish government documents, it is stated that a Central European Federation should include Lithuania, so that as a small country it could not be used in the future against Poland. Besides, Polish and Lithuanian access to the Baltic Sea would be wider and the defence of the northwestern boundary of Poland would be easier. It was also hoped that after the war East Prussia would not belong to Germany, and Lithuania as a member of the federation could govern a certain part of Prussia, while the major part was to be attached to Poland. ${ }^{8}$ Meanwhile, the Polish minister, Stanisław Stroński, commenting on the Polish-Czechoslovak Declaration, drew attention to the need to enlarge the Polish-Czechoslovak union and listed thirteen European states occupied by Hitler or Stalin, including Lithuania, Latvia, Estonia and Finland. On the Czechoslovak side the declaration was commented upon by Hubert Ripka. According to Polish sources, he interpreted it 'unexpectedly widely and bravely with respect to Russia'. Ripka maintained that it was necessary to reorganize the entire territory from the Baltic to the Black and Aegean Seas. The formation of three federations seemed quite realistic to him: (1) Poland and the Baltic States, (2) a Danube Federation (Czechoslovakia, Austria, Hungary and possibly Romania) and (3) a Balkan Federation. All the three were to be interdependent. ${ }^{9}$

By solving the problem of a Central European Federation, the Polish government was interested in Lithuania, Hungary and possibly Romania, in addition to Czechoslovakia. On the Czechoslovak side fears were sometimes expressed that Poland in comparison with Czechoslovakia could become too strong by forming a federation

${ }^{8}$ SIA, A. XII. 34/2, Kol. Sosnkowskiego. Uwagi o przyszlym układzie prawnopolitycznym w Europie Środkowej i Wschodniej [Notes on future legal and political organization in Central and Eastern Europe].

${ }^{9}$ T. Komarnicki, 'Próby stworzenia związku polsko-czechosłowskiego w okresie II wojny światowej’, Sprawy Międzynarodowe, no. 2-3, 1947, pp. 71-72. 
with Lithuania within the boundaries of a Central European Federation. However, such plans are not recorded in any Polish documents.

In June 1941 the policy committee of the Polish council of ministers presided over by Sosnkowski considered the Central European Union, and submitted a draft outline of the Constitutional Polish-Czechoslovak Union to the prime minister Sikorski. It was forwarded to the coordinatiing committee of Poland and Czechoslovakia, but the Czechoslovak side did not respond to it. This document appeared in the background of the discussions among various politicians and all kinds of specialists. Later in January 1942 the Czechoslovak side sent its Polish counterpart a short document, or rather a brief declaration of the principles of a Polish-Czechoslovak confederation. This document did not become the basis for discussion either, although the Polish side was prepared for this.

In his speech, delivered at the University of Aberdeen on 10 November 1941, Beneš argued for the first time that the unequivocal approval of the Soviet Union was a necessary condition for the creation of a union between Poland, Czechoslovakia and Central Europe, and this caused concern to the Poles. Polish-Czechoslovak talks about the union continued and the Polish side wanted to reach concrete binding agreements at any price.

On 7 January 1942 the then foreign minister Raczyński informed Beneš about Sikorski's visit to the USSR: 'I drew his attention to Soviet tactics clearly emphasizing their military victories in order to exploit them in the political sphere. Indicating Soviet territorial claims I quite openly indicated an item of paramount importance for us, namely Lithuania, the security of which is a particularly vital Polish concern and which we are going to include into a federative Central European union as a neighbouring country' ${ }^{10}$ As before, the Czechoslovak side did not present any conditions on this issue. However, in his meeting with Raczyński, Beneš did not touch upon this subject 'thus avoiding a statement for or against'. Raczyński suggested that Sikorski should raise this problem at his oncoming meeting with Beneš 'only in such a manner as not to provoke Russia, instead showing that it might even profit from it' ${ }^{11}$

On 11 January 1942 Polish-Lithuanian negotiations on Lithuania's joining a Central European Federation began in the Polish

${ }^{10}$ SIA, A. XII. 49/Cz/1B. Kol. Raczyńskiego. Raczyński’s account of his talk with Beneš, 7 Jan. 1942.

${ }^{11}$ Ibid., Notes of Sikorski's talk with Beneš, 22 Jan. 1942. 
embassy in London. Lithuania was represented by Lithuanian émigrés. Sikorski offered the Lithuanians support and urged them to raise the issue of Lithuania's independence internationally. At the same time Raczyński sent to the British Foreign Office a note about Poland's interest in Lithuania. Subsequently Polish-Lithuanian talks were discontinued due to a grave crisis in the issue of the Central European federation.

On 15 January 1942 the Greek and Yugoslav governments in exile signed a treaty on the formation of a Balkan union in London. This document was enthusiastically greeted by the Polish and Czechoslovak governments. In their speeches the Greek king George and the Yugoslav king Peter II expressed hope that a Balkan union and a Polish-Czechoslovak union would be based on the same principles in future leading to a wider Central European union. However, efforts to establish a Greek-Yugoslav union were thwarted immediately by the Yugoslav Communist leader Josip Broz Tito as soon as Great Britain recognized the provisional Yugoslav Communist government and did not recognize the émigré government. Tito followed a Soviet policy over this matter.

In May 1942 an event fell like a bombshell. Czechoslovakia celebrated Poland's national holiday - the anniversary of the Constitution of 3 May - as a token of friendship with Poland. In his reaction to this celebration the Soviet ambassador in London, Ivan Maisky, requested the unequivocal political self-determination of Czechoslovakia. A top-secret meeting of the State Council was convened in which, to Polish knowledge, the following secret resolution was supposed: 'Czechoslovakia acknowledges Poland's vital interests and at the same time the crucial interests of the Soviet Union; on the other hand Czechoslovakia cannot but take into account Lithuania's belonging to the Soviet Union since 1939'. The project of this resolution was opposed most categorically by seven members of the Council; six of them were Slovaks. The resolution had to be handed in to Maisky so that he could forward it to Vyacheslav Molotov who happened to be in London on his way to America and was intending to use it in the United States. Having learnt about that the Polish vice-premier and interior minister, Stanisław Mikołajczyk, informed the foreign minister Raczyński. In Mikołajczyk's opinion, as the text of the resolution became known to the Poles, the Czechoslovak State Council adopted a re-worded resolution: 'Czechoslovakia acknowledges Poland's vital interests and at the same time the crucial interests of the Union of the Soviet 
Socialist Republics'. In this document there was no mention of Lithuania. Due to Poland's interference all members of the State Council were questioned and each had to swear that they had not passed on any information about the session of the Council. ${ }^{12}$

While in London, Molotov met Beneš too. The notes of the Polish envoy to the Czechoslovak government Adam Tarnowski, submitted after the meeting with Beneš, show that Molotov 'viewed the project of a Polish-Czechoslovak federation unfavourably. President Beneš told Mr Molotov that he was ready to do everything possible that a Polish-Czechoslovak union (treaty) be created and assured Molotov that Czechoslovakia would in no way take an attitude unfavourable to the Soviet Union, while in Polish-Soviet territorial disputes Czechoslovakia would remain completely neutral'. The Poles considered as Soviet territory the area that belonged to it on 1 September 1939, while Molotov argued that the Soviet Union was the territory that belonged to it on the first day of the war, i.e. on 22 of June 1941. With regard to the Baltic states, 'President Beneš is actually an adherent of their independence ..., but he considers that Russia must have a better guaranteed access to the Baltic Sea than the present Leningrad corridor - in case of war that is a strategic necessity' 13 .

In December 1942 the Polish minister of state (Peace Conference Planning) Seyda, who prepared Poland for a peace congress that was supposed to take place after the war (it did not take place, as it is commonly known), presented the Polish war aims at a session of the Polish National Council. Amongst other things he indicated that Poland should receive 5,730 square kilometres of territory East-Prussia and Lithuania, if 'it resolved to enter the Central European Union', 329 square kilometres. Speaking about Central Europe, Seyda proposed the idea of a single rather integral union. He did not predetermine whether the bloc would consist of one or two federative or confederative unions. 'We leave this question open because in real life many changes are possible, for example, due to current Czech manoeuvres or the pressure applied by the Soviet Union'. In his opinion, the Central European bloc should include Poland, Czechoslovakia, Lithuania, Hungary, Romania, Yugoslavia, Bulgaria, Albania, Greece and probably Turkey. Austria,

12 Ibid., PRM 64/2, Note MSW, 29 May 1942.

${ }^{13}$ Ibid., A. XII. 49/Cz/1C. Kol. Raczyńskiego. Notes of Tarnowski's talk with Beneš, 29 June 1942. 
regarded by Seyda as Germany's tool, should not belong to the federation; neither should Latvia, Estonia and Finland. However, through mutual cooperation they could move towards the federation and become members in the course of time. At the same time Seyda did not approve of the federation's comprising the whole of Europe because Germany would play the dominant role in it. Neither did he endorse the idea of an Atlantic Federation that would comprise Western European countries and the United States because then the English-speaking states would turn away from 'Central and Northeastern Europe, and that would be advantageous to the Germans and the Soviets'.14

The idea of a Central European Federation was then unreal (if it ever was such) because neither the United States nor Great Britain were prepared and willing to support it and be embroiled in disputes and possibly even political conflicts with the Soviet Union. However, the idea of a Central European Federation remained alive after the war - in the first post-war years it was considered by representatives of political exiles from European countries - the Baltic States, Poland, Czechoslovakia and the Balkans, as well as Ukraine and Belarus. However, European integration steered quite a different course, and now, after the demise of Communism and the collapse the Soviet Union, all the countries of Central Europe will join the European Union sooner or later.

Translation: Alfonsas Laučka

Author Details

Professor Tadeusz Kisielewski, is head or member of several Polish historical research institutions. The sphere of his scholarly interests is the issues of current Polish and European political systems. Among his works Federacja środkowa europejska (Warsaw, 1991) should be mentioned.

Address: Instytut Nauk Politycznych, Uniwersytet Kazimierza Wielkiego w Bydgoszczy, Przemysłowa 34, 85-758 Bydgoszcz, Poland

Email: polityka@ukw.edu.pl

${ }^{14}$ Ibid., A. 5/48, minutes of the session of the national government, 1 Dec. 1942. 


\section{FEDERACINIAI PLANAI VIDURIO RYTU EUROPOJE IR BALTIJOS VALSTYBIU KLAUSIMAS ANTROJO PASAULINIO KARO METU LENKIJOS POLITIKOS KONTEKSTE}

Santrauka

\section{TADEUSZ KISIELEWSKI}

Straipsnyje aptariami Vidurio Rytu Europos (toliau - VRE) federacijos planai Antrojo pasaulinio karo metais. Tų planų igyvendinimo linkme aktyviai veikè Lenkijos emigrantinè vyriausybe ir jos partnere Čekoslovakijos emigrantinè vyriausybė. VRE federacija turejjo būti kaip eventuali atsvara Stalino planams susovietinti Europą iki Lamanšo arba iki Elbès ir Adrijos. Taip pat VRE vienijimasis galèjo būti alternatyva Hitlerio „Naujajai Europai“, kurios branduoli sudarytų Vokietijos-Italijos ašis, prie jos prisidètų Vichy Prancūzija bei Franko Ispanija, o ją turejo paremti Balkanų šalys ir galbūt JAV. Taip pasaulis būtų padalytas ị tris polius: vokiškajị, apimantị Europą, anglosaksiškaji, apimantị Ameriką ir Britų imperiją bei Japonijos Aziją. Lenkijai, kaip ir visam VRE regionui, tai būtų reiškę permanentinę nelaisvę.

Britanija ir JAV kurị laiką rèmė VRE federacijos planus, tačiau pamažu nuo jų atsitraukè nenoredamos karo metu konfliktuoti su SSRS. Be to, anglosaksiškuose politiniuose akademiniuose sluoksniuose buvo ir kitokių federacijos variantų. Pagal vienus iš jų, Vokietija, bet be Hitlerio, turejjo būti integruota į Vakarus patenkinant jos interesus VRE sąskaita. Tuo pačiu SSRS turèjo būti atribota nuo Europos. Pagal kitus planus, Rusija turèjo tapti slaviškų tautų garante VRE regione. Pastaroji koncepcija buvo populiari Oksfordo sluoksniuose (Bernardas Peresas, Hugo Seton-Watsonas), su kuriais ryšius palaike ir Čekoslovakijos emigrantinès vyriausybės vadovas E. Benešas.

1940 m. lapkričio 11 d. tarp Lenkijos ir Čekoslovakijos buvo pasirašyta deklaracija dèl federacijos kūrimo. Tuo metu abi pusès sutarè dèl eventualios federacijos išplètimo. Bet jau 1941 m. lapkričio 10 d. E. Benešas pasisakè už unijos planų derinimą su SSRS. Ryškejjo skirtumai tarp lenkų ir čekų Lietuvos klausimu.

1942 m. gegužę Čekoslovakijos Valstybès Taryba, spaudžiama Maiskio, prièmė rezoliuciją, kad ,pripažista ir Lenkijos interesus, ir SSRS gyvybinius interesus“. Tie interesai - tai Lietuva, nors ji ir nebuvo paminèta. O per $1942 \mathrm{~m}$. gegužès susitikimą su Molotovu Londone E. Benešas stengèsi užimti neutralią poziciją lenkųsovietų ginče.

Tam tikrą impulsą federaciniams planams suteikè $1942 \mathrm{~m}$. sausio 15 d. Graikijos-Jugoslavijos sutartis dèl Balkanų unijos, bet ją sužlugdė Broz Tito, kuris greitai gavo britų paramą.

Taigi E. Benešas buvo už uniją, kuriai pritartų SSRS. Be to, jis nesutiko paremti Rygos taikos linijos sutarties atkūrimo. O Lenkijos vyriausybè, nors ir nenorèjo konfrontuoti su SSRS, bet siekè savarankiškumo Maskvos atžvilgiu. E. Benešas buvo tik už laisvą konfederaciją ekonomikoje, o Lenkijos vadovas Wladislawas Sikorskis - už karinę-politinę sajungą.

1943 m. kovo 17 d. Čekoslovakijos vyriausybè dèl Maskvos spaudimo nutraukè derybas su Lenkijos vyriausybe. 